\section{Peranan Perhitungan Harga Pokok Produksi Pendekatan Full Costing Dalam Menentukan Harga Jual Dengan Metode Cost Plus Pricing Studi Kasus pada UMKM Sepatu Heriyanto}

\author{
Evi Noviasari dan Richad Alamsyah \\ Program Studi Akuntansi, Institut Bisnis dan Informatika Kesatuan \\ Bogor, Indonesia \\ E-Mail: evinoviasari40@gmail.com
}

Full Costing and Cost of Goods Manufacture

Submitted: JANUARI 2020

Accepted: APRIL 2020

\begin{abstract}
The purpose of this study were to know the role of calculation cost of goods manufactured and determination of the selling price of shoes in the Heriyanto's shoes MSME. To knowing the extent of differences in determination the cost of goods manufactured by using the company method and the full costing approach and compare the selling price according to the company's method with using the Cost Plus Pricing method. The type of research used is qualitative research. The analytical method used in this study is qualitative descriptive analysis. The data used in this study are primary data. Data were obtained directly through observation and interviews with the Heriyanto's shoes MSME and data in the form of information on production costs such as raw material costs, labor costs, and factory overhead costs MSME during December 2018. While for secondary data. Data were obtained from intermediary media such as books or literature, journals related to the title of the research, and can also be via the internet. The results of the study it can be concluded that the cost of goods manufactured calculation according Heriyanto's MSME is lower than the cost of goods manufactured calculation using the full costing method. The cost of goods manufactured according heriyanto's MSME is Rp. 15.675/pair or Rp. 313.492/score (Hamer Material) and Rp. 14.600/pair or Rp. 291.992/score (Kavaro Material). While the cost of goods manufactured used the full costing method, which is Rp. 16.310/pair or Rp. 326.201/score (Hamer Material) and Rp. 15.235/pair or Rp. 304.701/score (Kavaro Material). This is caused factory overhead costs that are not calculate by Heriyanto's MSME such as electricity costs, gas costs, maintenance costs for machinery and factory vehicles, and depreciation costs. Determination of selling price must be appropriately because the determination of selling prices that are too high will result in difficulty competition with similar products while the determination of selling prices too low will result in reduced income generated by Heriyanto's MSME. The difference in determination the cost of good manufactured will affect the Heriyanto's MSME in determining the selling price, because the cost of goods manufactured is the main element in determination selling price. Calculation of selling prices according Heriyanto's MSME is Rp. 18.026/pair or Rp. 360.516/score (Hamer Material) and Rp. 16.790/pair or Rp. 335.791/score (Kavaro material). While the selling price used the Cost Plus Pricing method which is Rp. 18.814/pair or Rp. 376.281/score (Hamer Material) and Rp. 17.578/pair or Rp. 351.556/score (Kavaro material).
\end{abstract}

Keywords: cost of goods manufactured, selling price, full costing, cost plus pricing

\title{
PENDAHULUAN
}

Perkembangan perekonomian di Indonesia saat ini semakin berkembang. Berdasarkan Lembaga kajian Centre of Reform on Economics (CORE) Indonesia memprediksi, pertumbuhan ekonomi di Indonesia dapat mencapai 5,1 persen hingga 5,2 persen. Tujuan suatu bisnis dilakukan selain untuk memenuhi kebutuhan konsumen adalah untuk meningkatkan keuntungan semaksimal mungkin dalam upaya memperluas bisnis dan menjaga kelangsungan hidup suatu bisnis. Meningkatkan

\section{JIAKES}

Jurnal Ilmiah Akuntansi Kesatuan Vol. 8 No. 1, 2020 pg. $17-26$ IBI Kesatuan ISSN $2337-7852$
E-ISSN $2721-3048$ 
Full Costing and

Cost of Goods

Manufacture

$\underline{18}$ keuntungan dalam suatu bisnis berkaitan dengan penentuan harga jual dari barang atau jasa yang di produksi, yang akan dijual kepada konsumen sehingga suatu bisnis dapat menghasilkan pendapatan untuk menutupi biaya yang dikeluarkan dalam memproduksi barang atau jasa tersebut.

Penentuan harga jual merupakan hal penting yang harus diputuskan seorang manajer untuk mendapatkan laba atas biaya yang telah dikeluarkan terhadap barang atau jasa yang dihasilkan. Dalam menentukan harga jual suatu barang atau jasa, manajer dapat memutuskan harga jual yang terlalu tinggi atau rendah dari pesaingnya. Menurut Mulyadi $(2010,348)$ empat metode penentuan harga jual yang biasanya digunakan oleh perusahaan yaitu penentuan harga jual dalam keadaan normal, penentuan harga jual dalam cost type contract, penentuan harga jual pesanan khusus, dan penentuan harga jual produk atau jasa yang dihasilkan oleh perusahaan yang diatur dengan peraturan Pemerintah. Dalam keempat metode penentuan harga jual tersebut, biaya merupakan titik tolak untuk perumusan kebijakan harga jual. Ada tiga metode mengenai penentuan harga jual berdasarkan biaya, yaitu cost plus pricing, mark up pricing, dan penentuan harga oleh produsen. Salah satu metode dalam penetapan harga jual terhadap barang atau jasa yang biasanya digunakan dalam suatu bisnis adalah cost plus pricing. Cost plus pricing atau harga jual barang atau jasa dalam keadaan normal adalah penentuan harga jual dengan cara menambah laba yang diharapkan di atas biaya penuh masa yang akan datang untuk memperoleh barang atau jasa.

Harga pokok produksi merupakan bagian penting yang diperlukan untuk menentukan harga jual produk. Ada dua pendekatan yang digunakan untuk menentukan harga pokok produksi yaitu metode full costing dan metode variable costing. Gersil dan Cevdet $(2016,79)$ mengungkapkan bahwa produksi tidak akan terjadi tanpa timbulnya biaya overhead pabrik tetap, maka full costing menganggap biaya overhead pabrik tetap sebagai biaya perolehan persediaan. Lebih lanjut Gersil dan Cevdet menjelaskan bahwa full costing lebih banyak digunakan oleh para manajer perusahaan untuk pengambilan keputusan jangka panjang, dan memungkinkan manajer perusahaan dalam meningkatkan pendapatan operasional dengan meningkatkan produksi bahkan ketika permintaan sedang surut. Perusahaan sering kali hanya mempertimbangkan biaya produksi dan laba yang diinginkan dalam menetapkan harga jual. Perusahaan tidak mempertimbangkan atau menghitung biaya nonproduksi yang dikeluarkan. Menurut Mulyadi $(2015,14)$ harga pokok produksi dalam pembuatan produk terdapat dua kelompok biaya yaitu biaya produksi dan biaya nonproduksi.

\section{TINJAUAN PUSTAKA \\ Harga Pokok Produksi}

Menurut Mulyadi $(2015,16)$ Harga pokok produksi adalah semua biaya yang dikeluarkan untuk memproduksi suatu barang atau jasa selama periode bersangkutan. Dengan kata lain, bahwa harga pokok produksi merupakan biaya yang dikeluarkan untuk mengolah bahan baku hingga menjadi barang jadi yang siap jual. Melakukan perhitungan harga pokok produksi perlu memperhatikan unsur-unsur biaya yang termasuk dalam harga pokok produksi itu sendiri dan metode yang digunakan dalam pengumpulan biaya produksi. Penentuan Harga pokok produksi itu ditentukan oleh bagaimana cara perusahaan tersebut berproduksi. Umumnya sifat pengolahan produk didasarkan atas pesanan dan pengolahan produk yang didasarkan pada proses. Metode pengumpulan biaya produksi dapat dibagi menjadi dua yaitu:

1. Metode Harga Pokok Pesanan (Job Order Cost Method). Dalam metode ini biayabiaya produksi dikumpulkan untuk pesanan tertentu dan kos produksi per satuan produk yang dihasilkan untuk memenuhi pesanan tersebut dihitung dengan cara membagi total biaya produksi untuk pesanan tersebut dengan jumlah satuan produk dalam pesanan yang bersangkutan. 
2. Metode Harga Pokok Proses (Process Cost Method). Dalam metode ini biaya-biaya produksi dikumpulkan untuk periode tertentu dan kos produksi per satuan produk yang dihasilkan dalam periode tersebut dihitung dengan cara membagi total biaya produksi untuk periode tersebut dengan jumlah satuan produk dalam periode yang bersangkutan.

Menurut Mulyadi $(2015,17)$ metode penentuan kos produksi adalah cara memperhitungkan unsur-unsur biaya kedalam kos produksi, dalam memperhitungkan unsur-unsur biaya kedalam kos produksi, terdapat dua pendekatan yaitu metode full costing dan metode variabel costing. Full costing adalah taksiran biaya penuh yang dipakai sebagai dasar penentuan harga jual yang terdiri dari biaya bahan baku, biaya tenaga kerja langsung, dan biaya overhead pabrik, baik yang berperilaku variabel maupun yang berperilaku tetap. Variabel costing merupakan penentuan kos produksi yang hanya memperhitungkan biaya produksi yang berperilaku variabel ke dalam kos produksi yang terdiri dari biaya bahan baku, biaya tenaga kerja langsung dan biaya overhead pabrik variabel.

\section{Harga Jual}

Menurut Soeprihanto dikutip dalam Samsul $(2013,368)$ harga jual adalah jumlah uang (ditambah beberapa produk kalau mungkin) mendapatkan sejumlah kombinasi dari barang beserta pelayanannya faktor-faktor yang mempengaruhi penetapan harga jual. Menurut Kristanti dalam Dian Purnama $(2017,38)$ metode cost plus pricing merupakan metode penentuan harga melalui pendekatan biaya yang didasarkan atas biaya produksi maupun biaya nonproduksi yang tidak lepas dari penentuan harga pokok produksi. Pada metode cost plus pricing semakin perusahaan memproduksi dalam jumlah yang banyak maka harga jualnya semakin murah, sebaliknya semakin perusahaan memproduksi dalam jumlah yang sedikit maka harga jual semakin mahal. Secara sederhana rumus dari metode cost plus pricing method adalah sebagai berikut:

Harga jual $=$ Taksiran biaya penuh + Margin laba

\section{METODOLOGI PENELITIAN}

Penelitian ini dilaksanakan di UMKM Heriyanto yang berlokasi di jalan JL E Sumawijaya Kampung Sindang Barang gang Jambekiuna Desa Pasir Eurih Kecamatan Taman sari Kabupaten Bogor. Waktu penelitian dilakukan pada bulan Desember 2018. Analisis dalam penelitian ini menggunakan Metode Deskriptif Kuantitatif dimana dalam penyusunan harga pokok produksi dan harga jual dinyatakan dengan angka. Prosedur penelitian yang dilakukan dalam pelaksanaan penelitian ini adalah sebagai berikut: Mencari objek yang sesuai dengan judul penelitian, Mengajukan surat permohonan penelitian untuk menyusun skripsi pada pimpinan UMKM Heriyanto, Mengumpulkan data-data pendukung yang akan diperlukan dan Pengolahan dan penyajian data.

Sumber data yang akan digunakan dalam penelitian ini adalah data primer dan data sekunder. Data primer adalah data yang diperoleh langsung melalui observasi dan wawancara dengan pihak UMKM sepatu Heriyanto yang memiliki pemahaman dalam permasalahan yang diteliti. Data sekunder adalah data yang diperoleh dari media perantara seperti buku-buku atau literatur-literatur, jurnal yang berkaitan dengan judul penelitian, dan dapat pula melalui internet.

\section{HASIL DAN PEMBAHASAN}

Harga Pokok Produksi dan Harga Jual Produk Yang Diterapkan UMKM Heriyanto

Berdasarkan Tabel 1 dapat dilihat bahwa total harga pokok produksi UMKM Heriyanto selama bulan Desember 2018 adalah sebesar Rp. 15.674.617 untuk sepatu bahan Hamer dengan harga pokok produksi per pasang sepatunya sebesar Rp. 15.675 dan harga pokok produksi untuk satu kodi sepatu sebesar Rp. 313.492. Total harga
Full Costing and Cost of Goods Manufacture 
Full Costing and Cost of Goods Manufacture

20 pokok produksi sebesar Rp. 20.439.463 untuk sepatu bahan Kavaro dengan harga pokok produksi per pasang sepatu Rp. 14.600 dan Rp. 291.992 untuk satu kodi. Total biaya tersebut di pengaruhi oleh biaya bahan baku, biaya tenaga kerja langsung dan biaya overhead pabrik.

Tabel 1 Harga Pokok Produksi Menurut UMKM Heriyanto

\begin{tabular}{|c|c|c|c|c|c|c|}
\hline Keterangan & $\begin{array}{c}\text { Total Biaya } \\
\text { (Rp) } \\
50 \text { kodi }\end{array}$ & $\begin{array}{c}\text { Biaya per } \\
\text { kodi } \\
(\mathrm{Rp}) \\
\text { Bahan } \\
\text { Hamer }\end{array}$ & $\begin{array}{c}\text { Biaya Per } \\
\text { Pasang } \\
(\mathrm{Rp}) \\
\text { Bahan } \\
\text { Hamer }\end{array}$ & $\begin{array}{c}\text { Total Biaya } \\
\text { (Rp) } \\
70 \text { kodi }\end{array}$ & $\begin{array}{c}\text { Biaya per } \\
\text { kodi } \\
\text { (Rp) } \\
\text { Bahan } \\
\text { Kavaro }\end{array}$ & $\begin{array}{c}\text { Biaya Per } \\
\text { Pasang } \\
(\mathrm{Rp}) \\
\text { Bahan } \\
\text { Kavaro }\end{array}$ \\
\hline $\begin{array}{l}\text { Biaya } \\
\text { Bahan } \\
\text { Baku }\end{array}$ & 11.682 .950 & 233.659 & $11.682,95$ & 14.816 .130 & 211.659 & $10.582,95$ \\
\hline $\begin{array}{l}\text { Biaya } \\
\text { Tenaga } \\
\text { Kerja } \\
\text { Langsung }\end{array}$ & 3.941 .667 & $78.833,34$ & $3.941,667$ & 5.553 .333 & $79.333,33$ & $3.966,666$ \\
\hline $\begin{array}{l}\text { Biaya } \\
\text { Overhead } \\
\text { Pabrik }\end{array}$ & 50.000 & 1.000 & 50 & 70.000 & 1.000 & 50 \\
\hline $\begin{array}{l}\text { Total } \\
\text { Harga } \\
\text { Pokok } \\
\text { Produksi }\end{array}$ & 15.674 .617 & 313.492 & 15.675 & 20.439 .463 & 291.992 & 14.600 \\
\hline
\end{tabular}

Sumber: Data UMKM Heriyanto karena Diolah, 2018.

Tabel 2 Harga Jual Sepatu Bahan Hamer dan kavaro Menurut UMKM Heriyanto

\begin{tabular}{lrr}
\hline \multicolumn{1}{c}{ Keterangan/kodi } & $\begin{array}{c}\text { Harga Jual Sepatu } \\
\text { Hamer }\end{array}$ & $\begin{array}{c}\text { Harga Jual Sepatu } \\
\text { Kavaro }\end{array}$ \\
\hline Biaya Bahan Baku & 233.659 & 211.659 \\
Biaya Tenaga Kerja Langsung & $78.833,34$ & $79.333,33$ \\
Biaya Overhead Pabrik & 1.000 & 1.000 \\
Harga Pokok Produksi & 313.492 & 291.992 \\
Margin Laba 15\% & 47.024 & 43.799 \\
Harga Jual & 360.516 & 335.791 \\
Unit Yang Diproduksi & 20 & 20 \\
Harga Jual Per pasang & 18.026 & 16.790 \\
\hline
\end{tabular}

Sumber: Data UMKM Heriyanto karena Diolah, 2018.

Dari perhitungan yang telah dilakukan harga jual per unit sepatu bahan hamer sebesar Rp. 18.026/pasang atau Rp. 360.516/kodi dan sepatu bahan kavaro sebesar Rp. 16.790/pasang atau Rp. 335.791/kodi. Apabila perusahaan menentukan harga jual yang terlalu mahal, karena disebabkan dari harga biaya bahan baku yang relatif naik.

\section{Harga Pokok Produksi Pendekatan Full Costing}

Berdasarkan perhitungan harga pokok produksi pendekatan Full Costing memasukan unsur biaya overhead pabrik yang tidak dirinci dalam perhitungan harga pokok produksi menurut UMKM Heriyanto. Adapun beberapa biaya overhead pabrik variabel yang berhubungan dengan proses produksi sepatu antara lain:

1. Biaya Bahan Penolong

Berdasarkan Tabel 3 biaya bahan penolong berjumlah Rp. 77.946/kodi dan untuk biaya per pasang dari biaya bahan penolong yaitu Rp. 3.897,3 jadi total biaya penolong untuk 120 kodi sepatu yang diproduksi di UMKm Heriyanto sebesar Rp. 9.353.520 yang dihasilkan dari perkalian antara harga biaya bahan penolong 1 kodi dengan jumlah sepatu yang di produksi yaitu sebanyak 120 kodi.

2. Biaya Listrik

Listrik yang digunakan oleh UMKM Heriyanto untuk mendukung kegiatan produksi di bengkel sepatu. Berdasarkan pengeluaran yang dilakukan setiap bulannya, UMKM Heriyanto membayar tagihan listrik sekitar $50 \%$ dari total biaya listrik perbulannya.. Biaya listrik untuk bengkel sepatu yaitu sekitar Rp. 150.000/bulan. 
Tabel 3 Biaya Bahan Penolong Menurut Metode Full Costing

\begin{tabular}{|c|c|c|c|c|c|}
\hline Keterangan & $\begin{array}{c}\text { Harga } \\
\text { (Rp) } \\
1\end{array}$ & $\begin{array}{c}\text { Kebutuhan } \\
\text { Per Kodi } \\
2\end{array}$ & Satuan & $\begin{array}{c}\text { Biaya/ } \\
\text { Kodi } \\
(\mathrm{Rp}) \\
3=1 \times 2\end{array}$ & $\begin{array}{c}\text { Biaya/ } \\
\text { pasang } \\
(\mathrm{Rp}) \\
4=3 / 20\end{array}$ \\
\hline Embos merk & $2.000 /$ kodi & 40 & Kali & 2.000 & 100 \\
\hline Lem Latek & 13.000/liter & 1 & Liter & 13.000 & 650 \\
\hline Benang Jahit & $1.000 /$ gross & 1 & Gross & 1.000 & 50 \\
\hline Aksesoris & 20.000/kodi & 40 & Buah & 20.000 & 1.000 \\
\hline Nomor Ukuran & $180.000 / \mathrm{pak}$ & 40 & Buah & 300 & 15 \\
\hline Plastik & $25.000 / \mathrm{kg}$ & 4 & Buah & 3.125 & 156,25 \\
\hline Kardus & 20.000/kodi & 20 & Buah & 20.000 & 1.000 \\
\hline Lem Tempel Kuning & $250.000 /$ blek & \multicolumn{2}{|c|}{ Estimasi } & 8.333 & 416,65 \\
\hline Lem Tempel Putih & 300.000/blek & \multicolumn{2}{|c|}{ Estimasi } & 8.571 & 428,55 \\
\hline Pulpen Putih & 1600/buah & \multicolumn{2}{|c|}{ Estimasi } & 800 & 40 \\
\hline Pulpen Biru & $500 /$ buah & \multicolumn{2}{|c|}{ Estimasi } & 250 & 12,5 \\
\hline Tali Rapia & 17.000/golong & \multicolumn{2}{|c|}{ Estimasi } & 567 & 28,35 \\
\hline \multicolumn{4}{|c|}{ Biaya Bahan Baku per pasang $(\mathrm{Rp})$} & 77.946 & $3.897,3$ \\
\hline
\end{tabular}

Sumber: Data UMKM Heriyanto Diolah, 2018.

3. Biaya Gas

Biaya gas yang digunakan UMKM Heriyanto biasanya untuk membantu kegiatan proses produksi dalam pembuatan sepatu. Biaya gas bulan Desember yaitu sebesar Rp. 160.000 .

4. Biaya Pemeliharaan Mesin dan Kendaraan Pabrik

Berdasarkan tabel 4 biaya pemeliharaan mesin dan kendaraan yang dikeluarkan UMKM Heriyanto untuk mendukung kegiatan proses produksi berjumlah Rp. $80.000 /$ bulan.

Table 4. Biaya Pemeliharaan Mesin dan Kendaraan Pabrik Menurut Metode Full Costing

\begin{tabular}{|c|c|}
\hline Keterangan & Biaya (Rp) \\
\hline Biaya pemeliharaan motor pabrik & 50.000 \\
\hline Pelumas mesin jahit & 5.000 \\
\hline Biaya pemeliharaan mesin jahit & 25.000 \\
\hline
\end{tabular}

Sumber: Data UMKM Heriyanto karena Diolah, 2018

Tabel 5 Biaya Overhead Pabrik Variabel Menurut Metode Full Costing

\begin{tabular}{lc}
\hline \multicolumn{1}{c}{ Keterangan } & Biaya per pasang (Rp) \\
\hline Biaya bahan penolong & $3.897,3$ \\
Biaya Listrik & 62,5 \\
Biaya gas & 66,667 \\
Biaya pemeliharaan mesin dan kendaraan & 33,333 \\
Pabrik & \\
Total & $4.059,8$ \\
\hline
\end{tabular}

Sumber: Data UMKM Heriyanto karena Diolah, 2018

Adapun Biaya Overhead Pabrik Tetap yang terkait adalah hanya biaya penyusutan. Berdasarkan Tabel 6 biaya penyusutan dari peralatan dan mesin berjumlah Rp. 15.060.000/tahun. Biaya penyusutan perbulannya adalah sebesar Rp. 1.225.000 sehingga beban penyusutan sepatu bahan hamer dan kavaro adalah sebesar Rp. $522,917 /$ pasang. Biaya overhead pabrik tetap hanya terdiri dari biaya penyusutan. Berikut rincian biaya overhead pabrik tetap yang dapat dilihat pada tabel 7. Berdasarkan tabel 7 biaya overhead pabrik tetap untuk satu unit sepatu yaitu berjumlah Rp. 522,917 atau sebesar Rp. 1.225.000 selama sebulan.
Full Costing and Cost of Goods Manufacture 
Full Costing and

Cost of Goods

Manufacture

22

Tabel 6 Biaya Penyusutan Menurut Metode Full Costing

\begin{tabular}{|c|c|c|c|c|c|}
\hline Keterangan & $\begin{array}{c}\text { Harga Per } \\
\text { unit }(\mathrm{Rp}) \\
1\end{array}$ & $\begin{array}{c}\text { Jumlah } \\
\text { (Unit) } \\
2\end{array}$ & $\begin{array}{c}\text { Harga Beli } \\
\text { (Rp) } \\
3=1 \times 2\end{array}$ & $\begin{array}{c}\text { Umur } \\
\text { Eknmis (Thn) } \\
4\end{array}$ & $\begin{array}{c}\text { Biaya Penyusutan } \\
\text { (Rp/Tahun) } \\
5=3 / 4\end{array}$ \\
\hline Mesin Jahit & 400.000 & 7 & 2.800 .000 & 5 & 560.000 \\
\hline Mobil & 85.000 .000 & 1 & 85.000 .000 & 10 & 8.500 .000 \\
\hline Motor & 30.000 .000 & 1 & 30.000 .000 & 5 & 6.000 .000 \\
\hline Total & & & & & 15.060 .000 \\
\hline
\end{tabular}

Sumber: Data UMKM Heriyanto karena Diolah, 2018

Tabel 7. Biaya Overhead Pabrik Tetap Menurut Metode Full Costing

\begin{tabular}{lc}
\hline \multicolumn{1}{c}{ Keterangan } & Biaya per pasang (Rp) \\
Biaya penyusutan & 522,917 \\
Total & 522,917 \\
\hline
\end{tabular}

Sumber: Data UMKM Heriyanto karena Diolah, 2018

Tabel 8 Harga Pokok Produksi Menurut Metode Full Costing (Dalam SatuanRupiah)

\begin{tabular}{|c|c|c|c|c|c|c|}
\hline Keterangan & $\begin{array}{l}\text { Total Biaya } \\
50 \text { kodi }\end{array}$ & $\begin{array}{c}\text { Biaya per } \\
\text { kodi } \\
\text { Bahan } \\
\text { Hamer }\end{array}$ & $\begin{array}{c}\text { Biaya Per } \\
\text { Pasang } \\
\text { Bahan } \\
\text { Hamer }\end{array}$ & $\begin{array}{c}\text { Total } \\
\text { Biaya } \\
70 \text { kodi }\end{array}$ & $\begin{array}{c}\text { Biaya per } \\
\text { kodi } \\
\text { Bahan } \\
\text { Kavaro }\end{array}$ & $\begin{array}{c}\text { Biaya Per } \\
\text { Pasang } \\
\text { Bahan } \\
\text { Kavaro }\end{array}$ \\
\hline Biaya Bahan Baku & 7.785 .650 & 155.713 & $7.785,65$ & 9.359 .910 & 133.713 & $6.685,65$ \\
\hline $\begin{array}{l}\text { Biaya Tenaga Kerja } \\
\text { Langsung }\end{array}$ & 3.941 .667 & $78.833,34$ & $3.941,667$ & 5.553 .333 & $79.333,33$ & $3.966,666$ \\
\hline $\begin{array}{l}\text { Biaya Overhead Pabrik: } \\
\text { Biaya Overhead Pabrik } \\
\text { Variabel }\end{array}$ & 4.059 .800 & 81.196 & $4.059,8$ & 5.683 .720 & 81.196 & $4.059,8$ \\
\hline $\begin{array}{l}\text { Biaya Overhead Pabrik } \\
\text { Tetap }\end{array}$ & 522.917 & $10.458,34$ & 522,917 & $732.083,8$ & $10.458,34$ & 522,917 \\
\hline Harga Pokok Produksi & 16.310 .034 & 326.201 & 16.310 & 21.329 .047 & 304.701 & 15.235 \\
\hline
\end{tabular}

Sumber: Data UMKM Heriyanto karena Diolah, 2018

Berdasarkan tabel 8 Perhitungan harga pokok produksi menggunakan metode full costing memiliki hasil yang lebih tinggi dibandingkan dengan metode yang digunakan oleh UMKM. Harga pokok produksi menggunakan metode full costing untuk sepatu bahan hamer yaitu sebesar Rp. 16.310/pasang dan Rp. 326.201 untuk satu kodi sepatu dan total harga pokok produksi 50 kodi sepatu bahan hamer yaitu sebesar Rp. 16.310.034. Sedangkan untuk sepatu bahan kavaro memiliki harga Rp. 15.235/pasang dan Rp. 304.701/kodi dengan total harga pokok produksi sebesar Rp. 21.329.047 untuk 70 kodi sepatu bahan kavaro.

Harga Jual dengan Metode Cost Plus Pricing

Tabel 9 Harga Jual Sepatu Bahan Hamer dan kavaro Metode Cost Plus Pricing

\begin{tabular}{lcc}
\hline \multicolumn{1}{c}{ Keterangan/kodi } & Harga Jual Sepatu Hamer & Harga Jual Sepatu Kavaro \\
\hline Biaya Bahan Baku & 155.713 & 133.713 \\
By Tenaga Kerja Langsung & $78.833,34$ & $79.333,33$ \\
Biaya Overhead Pabrik & 92.655 & 92.655 \\
Harga Pokok Produksi & 327.201 & 305.701 \\
Margin Laba 15\% & 49.080 & 45.855 \\
Harga Jual & 376.281 & 351.556 \\
Unit Yang Diproduksi & 20 & 20 \\
Harga Jual Per pasang & 18.814 & 17.578 \\
\hline
\end{tabular}

Sumber: Data UMKM Heriyanto karena Diolah, 2018

Berdasarkan perhitungan harga jual menggunakan metode cost plus pricing yang telah dilakukan, dapat disimpulkan bahwa harga jual sepatu bahan hamer yaitu Rp. 18.814/pasang dan Rp. 376.281/kodi yang dihasilkan dari harga per pasang dikalikan dengan 20 pasang sepatu karena dalam 1 kodi sepatu berisi 20 pasang. Dan untuk harga jual sepatu bahan kavaro adalah sebesar Rp. Rp. 17.578/pasang dan Rp 351.556/kodi. 


\author{
Perbandingan Harga Pokok Produksi Menurut UMKM dan Menurut Metode Full \\ Costing
}

Harga pokok produksi merupakan total biaya produksi yang dikeluarkan dalam melakukan proses produksi sepatu. Dalam menentukan harga pokok produksi penulis menggunakan pendekatan full costing. Karena pendekatan full costing menghitung semua unsur biaya baik yang berperilaku variabel maupun tetap. Berdasarkan penelitian yang telah dilakukan oleh penulis ditemukan biaya yang belum dimasukan kedalam unsur harga pokok produksi seperti biaya penyusutan, biaya gas, biaya listrik dan biaya pemeliharaan mesin dan kendaraan pabrik.

Tabel 10 Perbandingan Harga Pokok Produksi Menurut UMKM dan Metode Full Costing

\begin{tabular}{|c|c|c|c|c|c|c|}
\hline \multirow[b]{2}{*}{ Keterangan } & \multicolumn{2}{|c|}{ Total Biaya } & \multicolumn{2}{|c|}{ Per Kodi } & \multicolumn{2}{|c|}{ Per Pasang } \\
\hline & $\begin{array}{l}\text { Bahan } \\
\text { Hamer }\end{array}$ & $\begin{array}{c}\text { Bahan } \\
\text { Kavaro }\end{array}$ & $\begin{array}{l}\text { Bahan } \\
\text { Hamer }\end{array}$ & $\begin{array}{c}\text { Bahan } \\
\text { Kavaro }\end{array}$ & $\begin{array}{l}\text { Bahan } \\
\text { Hamer }\end{array}$ & $\begin{array}{l}\text { Bahan } \\
\text { Kavaro }\end{array}$ \\
\hline $\begin{array}{l}\text { Harga Pokok } \\
\text { Produksi } \\
\text { Metode }\end{array}$ & 15.674 .617 & 20.439 .463 & 313.492 & 291.992 & 15.675 & 14.600 \\
\hline $\begin{array}{l}\text { UMKM (Rp) } \\
\text { Harga Pokok }\end{array}$ & & & & & & \\
\hline $\begin{array}{l}\text { Produksi } \\
\text { Metode Full } \\
\text { Costing (Rp) }\end{array}$ & 16.310 .034 & 21.329 .047 & 326.201 & 304.701 & 16.310 & 15.235 \\
\hline $\begin{array}{l}\text { Selisih Kedua } \\
\text { Metode (Rp) }\end{array}$ & 635.417 & 889.584 & 12.709 & 12.709 & 635 & 635 \\
\hline
\end{tabular}

Sumber: Data UMKM Heriyanto karena Diolah, 2018

Berdasarkan tabel 10, harga pokok produksi menurut UMKM dan menurut full costing menghasilkan perbedaan nilai. Perbedaan nilai yang dihasilkan disebabkan karena penggunaan metode UMKM yang tidak memasukan biaya overhead pabrik secara rinci kedalam perhitungan harga pokok produksinya. Harga pokok produksi yang dihasilkan menggunakan metode full costing menghasilkan harga pokok produksi yang lebih besar dibandingkan dengan metode menurut UMKM. Berdasarkan perhitungan harga pokok produksi pendekatan full costing maka dapat ditentukan selisih harga pokok produksi untuk bahan hamer dan bahan kavaro yaitu sebesar Rp. 635/pasang sedangkan selisih perbedaan harga pokok produksi per kodinya sebesar Rp. 12.709 untuk sepatu bahan hamer dan bahan kavaro. Untuk selisih perbedaan total harga pokok produksi sepatu bahan hamer yaitu sebesar Rp. 635.417 dan selisih sepatu bahan kavaro yaitu sebesar Rp. 889.584. Perhitungan dengan menggunakan metode full costing akan berguna bagi UMKM Heriyanto dalam melaksanakan kegiatan produksi sepatu maupun menetapkan harga jual yang akurat yang dapat menutupi semua biaya yang dikeluarkan dalam memproduksi sepatu sehingga dapat memperoleh keuntungan yang diharapkan UMKM Heriyanto.

\section{Perbandingan Harga Jual Menurut UMKM dan Menurut Metode Cost Plus Pricing}

Dari keempat metode penentuan harga jual penulis menggunakan penentuan harga jual menggunakan. Harga jual metode cost plus pricing atau harga jual dalam keadaan normal lebih banyak di gunakan oleh perusahaan untuk menentukan harga jual karena dapat menutupi semua biaya yang dikeluarkan untuk menghasilkan laba yang diharapkan. Penentuan harga jual untuk sepatu bahan Hamer dan bahan Kavaro dilakukan pada bulan Desember tahun 2018. Penelitian ini dilakukan dalam jangka waktu sebulan karena terbatasnya data yang dimiliki oleh UMKM Heriyanto.

Berdasarkan Tabel 1, harga jual menurut UMKM dan harga jual menurut metode full costing menghasilkan perbedaan nilai. Perbedaan nilai yang dihasilkan disebabkan karena perhitungan harga pokok produksi yang berbeda. Harga jual menurut metode cost plus pricing menghasilkan harga jual yang lebih tinggi dari pada pada menurut perusahaan. Karena harga jual metode cost plus pricing memperhitungkan semua biaya
Full Costing and Cost of Goods Manufacture 
Full Costing and Cost of Goods Manufacture

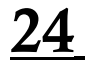

yang dikeluarkan dalam proses produksi baik biaya produksi maupun biaya non produksi seperti biaya penyusutan, biaya gas, biaya listrik dan biaya pemeliharaan mesin dan kendaraan pabrik yang kemudian di tambahkan dengan margin laba yang diharapkan.

Tabel 11 Perbandingan Harga Jual Menurut UMKM dan Metode Full Costing

\begin{tabular}{|c|c|c|c|c|c|c|}
\hline \multirow[b]{2}{*}{ Keterangan } & \multicolumn{2}{|c|}{ Total Biaya } & \multicolumn{2}{|c|}{ Per Kodi } & \multicolumn{2}{|c|}{ Per Pasang } \\
\hline & $\begin{array}{l}\text { Bahan } \\
\text { Hamer }\end{array}$ & $\begin{array}{c}\text { Bahan } \\
\text { Kavaro }\end{array}$ & $\begin{array}{l}\text { Bahan } \\
\text { Hamer }\end{array}$ & $\begin{array}{c}\text { Bahan } \\
\text { Kavaro }\end{array}$ & $\begin{array}{l}\text { Bahan } \\
\text { Hamer }\end{array}$ & $\begin{array}{l}\text { Bahan } \\
\text { Kavaro }\end{array}$ \\
\hline $\begin{array}{l}\text { Harga Jual } \\
\text { Metode UMKM } \\
\text { (Rp) }\end{array}$ & 18.025 .810 & 23.505 .382 & 360.516 & 335.791 & 18.026 & 16.790 \\
\hline $\begin{array}{l}\text { Harga Jual } \\
\text { Metode Full } \\
\text { Costing (Rp) }\end{array}$ & 18.814 .039 & 24.608 .904 & 376.281 & 351.556 & 18.814 & 17.578 \\
\hline $\begin{array}{l}\text { Selisih Kedua } \\
\text { Metode (Rp) }\end{array}$ & 788.229 & 1.103 .522 & 15.765 & 15.765 & 788 & 788 \\
\hline
\end{tabular}

Sumber: Data UMKM Heriyanto karena Diolah, 2018

Berdasarkan perhitungan harga jual metode cost plus pricing maka dapat ditentukan selisih harga jual untuk bahan hamer dan kavaro yaitu sebesar Rp. 788/pasang sedangkan selisih harga jual per kodi untuk bahan hamer dan bahan kavaro sebesar Rp. 15.765 dan selisih total dari harga jual sepatu bahan hamer yaitu sebesar Rp. 788.229 dan Rp. 1.103.522 untuk sepatu bahan kavaro. Penentuan harga jual dengan menggunakan metode cost plus pricing dapat menghasilkan harga jual yang lebih tepat karena menghitung semua biaya yang dikeluarkan dan harga jual tersebut dapat bersaing dengan perusahaan sejenis.

\section{PENUTUP}

Berdasarkan hasil analisis dan pembahasan yang telah diuraian, maka dapat disimpulkan bahwa:

1. Harga pokok produksi pendekatan Full Costing di UMKM Heriyanto adalah sebesar Rp. 326.201/kodi atau Rp. 16.310/pasang untuk sepatu bahan hamer dan Rp. 304.701/kodi atau Rp. 15.235/pasang sepatu bahan kavaro.

2. Harga jual dengan metode Cost Plus Pricing di UMKM Heriyanto adalah sebesar Rp. 376.281/kodi atau sebesar Rp.18.814/pasang untuk sepatu bahan hamer dan Rp. 351.556/kodi atau sebesar Rp. 17.578/pasang untuk sepatu bahan kavaro.

3. Berdasarkan perhitungan yang telah dilakukan maka dapat disimpulkan bahwa perhitungan harga pokok produksi pendekatan Full Costing dan harga jual metode Cost Plus Pricing menghasilkan nilai yang lebih tinggi dari pada perhitungan harga pokok produksi dan harga jual menurut metode perusahaan. Selisih harga pokok produksi menurut perusahaan dengan pendekatan Full Costing adalah sebesar Rp. 12.709/kodi atau Rp. 635/pasang untuk sepatu bahan hamer dan kavaro. Perbedaan nilai tersebut disebabkan karena perusahaan belum memasukan biaya overhead pabrik secara rinci seperti biaya gas, biaya listrik, biaya pemeliharaan mesin dan kendaraan pabrik serta biaya penyusutan aset tetap. Karena perbedaan dari harga pokok produksi maka menghasilkan harga jual yang berbeda pula antara menurut perusahaan dengan metode Cost Plus Pricing. Perbedaan tersebut adalah sebesar Rp. 15.765/kodi atau Rp. 788/pasang untuk sepatu bahan hamer dan kavaro yang seharusnya menjadi laba potensial bagi perusahaan.

Keterbatasan dalam penelitian ini adalah hanya meneliti biaya produksi dan biaya non produksi berdasarkan wawancara secara langsung dengan pemilik dan pekerja yang ada di UMKM Heriyanto. UMKM Heriyanto tidak mencatat secara tertulis biaya yang dikeluarkan dalam proses produksi. Data yang didapat dari perusahaan merupakan data yang terbatas sehingga penelitian hanya dapat mengolah data yang diberikan perusahaan. Berdasarkan kesimpulan yang telah dijelaskan diatas, maka penulis 
memberikan rekomendasi kepada UMKM Heriyanto agar melakukan perhitungan harga pokok produksi dengan rinci dan memasukan semua biaya yang dikeluarkan dalam proses produksi seperti memasukan biaya gas, biaya listrik, biaya pemeliharaan mesin dan kendaraan pabrik serta biaya penyusutan aset tetap sehingga UMKM Heriyanto dapat menghitung harga pokok produksi yang tepat dan melakukan pencatatan biaya yang dikeluarkan untuk membuat laporan harga pokok produksi yang berguna sebagai dasar penentuan harga jual produk yang dihasilkan. Dengan pembuatan laporan harga pokok produksi akan memudahkan UMKM Heriyanto dalam mengembangkan usahanya karena dengan perkembangan ekonomi yang semakin berkembang di Indonesia akan berguna bagi UMKM Heriyanto untuk menjaga kelangsungan usahanya serta meningkatkan usahanya menjadi semakin besar.

\section{DAFTAR PUSTAKA}

Astarani, M. dan Uliana, A. 2013. Analisis Penentuan Biaya Produksi Listrik Dengan Metode Full Costing Pada PT.PLN (Persero) Wilayah Kalimantan Barat Area Pontianak. Jurnal Audit dan Akuntansi. Universitas Tanjungpura, Pontianak.

Adi, S., Martani, D., Pamungkas, B. and Simanjuntak, R.A., 2016. Analysis of the quality of performance report of the local government on websites: Indonesian case. Cogent Business \& Management, 3(1), p.1229393.

Firmansyah, I., 2014. Akuntansi Biaya itu Gampang, Dunia Cerdas, Jakarta.

Iriyadi, I., 2019. Prevention of Earnings Management through Audit Committee and Audit Quality in the Award-Winning and Non-Winning Companies. Journal of Accounting Research, Organization and Economics, 2(2), pp.155-169.

Kembauw, E., Munawar, A., Purwanto, M.R., Budiasih, Y. and Utami, Y., 2020. Strategies of Financial Management Quality Control in Business.

Krismiaji., dan Aryani, Y Anni. 2011. Akuntansi Manajemen. Edisi Kedua. Sekolah Tinggi Ilmu Manajemen YKPN. Yogyakarta.

Mulyadi. 2010. Akuntansi Manajemen Konsep Manfaat dan Rekayasa. Edisi Ketiga, Salemba Empat, Jakarta.

Mulyadi. 2015. Akuntansi Biaya. Edisi 5. Unit Penerbit dan Percetakan Sekolah Tinggi Ilmu Manajemen YKPN, Graha Ilmu, Yogyakarta.

Mulyana, M., Hidayat, L. and Puspitasari, R., 2019. Mengukur Pengetahuan Investasi Para Mahasiswa Untuk Pengembangan Galeri Investasi Perguruan Tinggi. JAS-PT (Jurnal Analisis Sistem Pendidikan Tinggi Indonesia), 3(1), pp.31-52.

Munawar, A., 2010. Analisis Nilai Tambah Dan Pemasaran Kayu Sengon Gergajian (Studi Kasus di Kecamatan Cigudeg Kabupaten Bogor).

Pamungkas, B. and Afrianti, V., 2006. Evaluasi Akuntansi Pertanggungjawaban sebagai Alat Bantu Manajemen dalam Pengendalian Biaya: Studi Kasus pada PT. Cahaya Buana Intitama. Jurnal Ilmiah Ranggagading (JIR), 6(1), pp.7-13.

Rudianto., 2013. Akuntansi Manajemen Informasi untuk Pengambilan Keputusan Strategi, Erlangga, Jakarta.

Setiawan, B., Puspitasari, R. and Manurung, T.M.S., 2016. The existence of Islamic banking in Indonesia from non-muslims perceptions. ASEAN Marketing Journal, pp.81-96.

Sujarweni., V.W., 2015. Akuntansi Biaya Teori dan Penerapannya, Pustaka Baru Press, Yogyakarta.

Swastha, Basu D., 2010. Manajemen Penjualan Pelaksanaan Penjualan, BPFE. Yogyakarta.

Susilawati, N. and Supriadi, Y., 2017. Pengaruh Cash Ratio dan Siklus Konversi Kas Terhadap Profitabilitas Perusahaan. Jurnal Ilmiah Manajemen Kesatuan, 5(2), pp.115-124.
Full Costing and Cost of Goods Manufacture 
Full Costing and Cost of Goods Manufacture

\section{6}

Widyastuti, T., 2017. Akuntansi Biaya pendekatan Activity Based Costing, Expert, Yogyakarta.

Witjaksono, A., 2013. Akuntansi Biaya. Edisi Revisi, Graha Ilmu, Yogyakarta.

Laelisneni \& Rini Beutari Dian., 2017. Analisis Penetapan Harga Jual dalam Perencanaan Laba pada Home Industri Tempe Setia Budi Medan. Jurnal Bisnis Administrasi. Vol 06, Nomor 01, 2017, 52-60.

Purba, J.H., 2001. Model Ekonometrika Kelapa Sawit Indonesia, Analisis Simulasi Kebijakan Internal dan Eksternal. Jurnal Kopertis Wilayah, 4, p.12.

Purba, J.H.V., 2001. Keragaan Kelapa Sawit Indonesia Ditinjau dari Jenis Pengusahaan dan Wilayah Produksi (Doctoral dissertation, Doctoral dissertation, Tesis Magister Sains. Program Pascasarjana, Institut Pertanian Bogor, Bogor).

Purba, J.H.V. and Magdalena, A., 2017. Pengaruh Nilai Tukar Terhadap Ekspor dan Dampaknya Terhadap Pertumbuhan Ekonomi Indonesia. DeReMa Jurnal Manajemen, 12(2), pp.285-295.

Purnama, D., 2017. Perhitungan Harga Pokok Produksi dalam Menentukan Harga Jual Melalui Metode cost Plus Pricing dengan Pendekatan Full Costing: Studi pada PT Prima Istiqamah Sejahtera di Makassar.

Putriarisma Y H, Dhevi., 2016. Pengaruh Arus Kas dan Laba Bersih Terhadap Return Saham: Studi Kasus pada Perusahaan Pertambangan sub Sektor Batubara yang Terdaftar Di Bursa Efek Indonesia periode 2010-2014).

Putri, D.S. and Muktiadji, N., 2017. Analisis Portfolio Optimal Pada Beberapa Perusahaan LQ-45 Komparasi Pendekatan Markowits Dan Model Indeks Tunggal. Jurnal Ilmiah Manajemen Kesatuan, 5(1), pp.33-43.

Setiyorini, D. 2015. Penetapan Harga Jual Produk dengan Cost Plus Pricing Menggunakan Pendekatan Full Costing, Jurnal Universitas Dian Nuswantoro:2-11.

Soei, C.N., Sabijono, H. dan Runtu, T., 2014. Penentuan Harga Jual Produk dengan Menggunakan Metode Cost Plus Pricing: Pada UD. Sinar Sakti. Jurnal EMBA. Vol 2(3): 208-217.

Toar, O., Karamoy, H., dan Wokas, H. 2017. Analisis Perbandingan Harga Jual Produk Menggunakan Metode Cost Plus Pricing dan Mark Up Pricing pada Dolphin Donuts Bakery. Jurnal EMBA. Vol 5(2); 2040-2050.

Wuryansari, A., 2016. Analisis Perhitungan Harga Pokok Produksi dengan Menggunakan Metode Full Costing sebagai Dasar Penentuan Harga Jual: Studi di Peternakan Seraphine Yogyakarta.

Zuhdi, S., Daud, A., Hanif, R., Nguyen, P.T. and Shankar, K., 2019. Role of Social Media Marketing in the Successful Implementation of Business Management. International Journal of Recent Technology and Engineering, 8 (2S11). 